\title{
EO-MINERS: MONITORING THE ENVIRONMENTAL AND SOCIETAL IMPACT OF THE EXTRACTIVE INDUSTRY USING EARTH OBSERVATION
}

\author{
Colm J. Jordan ${ }^{(1)}$, Stephane Chevrel(2); Henk Coetzee ${ }^{(3)}$ Eyal Ben-Dor $^{(4)}$, Christoph Ehrler ${ }^{(5)}$, Christian \\ Fischer ${ }^{(5)}$, Stephen R. Grebby ${ }^{(1)}$, Gregoire Kerr ${ }^{(5)}$, Ido Livne ${ }^{(4)}$, Veronika Kopačková ${ }^{(6)}$, Ernis Kylychbaev(7), \\ Fiona McEvoy ${ }^{(1)}$, Simon Adar ${ }^{(8)}$
}

(1) British Geological Survey, Earth and Planetary Observation and Monitoring, Nottingham, UK Email: cjj@bgs.ac.uk

(2) BRGM, Mineral Resources, BP 36009, 45060 Orleans Cedex 2, France

(3) Council of Geosciences, Environmental Geosciences, South Africa

(4) Tel Aviv University, Department of Geography, Israel

(5) German Aerospace Center, Land Surface Department, Germany

(6) Czech Geological Survey, Klárov 3, Prague 1, Czech Republic

(7) Central Asian Institute for Applied Geosciences, Bishkek, Kyrgyzstan

(8) Tel Aviv University, Porter school of Environmental studies, Israel

\begin{abstract}
The growing demand for mineral and energy resources over the last decade has placed the extractive industry under increasing pressure to monitor and reduce the environmental and societal impact throughout the life-cycle of mining operations. Despite the mounting pressure, the industry is still facing the challenge of how to define targets for, and monitor, the impact of mining.
\end{abstract}

In 2010, the EU-funded EO-MINERS project (Earth Observation for Monitoring and Observing Environmental and Societal Impacts of Mineral Resources Exploration and Exploitation) was set up in an effort to help address this issue, specifically through the application of Earth Observation (EO) data. Furthermore, the aim was to help facilitate and improve interaction and dialogue between the mineral extractive industry and society in view of its sustainable development, while improving its societal acceptability. One of the primary project objectives was to develop novel yet objective EO products contributing to a constructive "trialogue" involving stakeholders such as industrialists (mining companies), regulatory bodies and the civil society. EOMINERS is scheduled to run until October 2013.

\section{Methodology}

The methodology of the project can be outlined as policy assessment $>$ indicator identification $>$ choice of suitable EO tools able to undertake monitoring task > social dialogue among stakeholders involved based on the objective EO-Products.

Indicators associated with environmental and societal mining impacts were defined using a combination of project expertise and extensive on-site interviews with stakeholders. The full set of indicators was then subset to those that can be measured using EO techniques, with the aim of demonstrating the capability of EO to help monitor and reduce the impacts, from the exploration phase through to extraction and remediation. Three case study areas with contrasting mineral resources, mining types and societal structures were used: the Witbank coalfield in South Africa, the Sokolov lignite opencast mine in the Czech Republic and the Makmal gold mine in Kyrgyzstan. For each study area, a list of the mining-related environmental and societal indicators was compiled following discussions with stakeholders. 


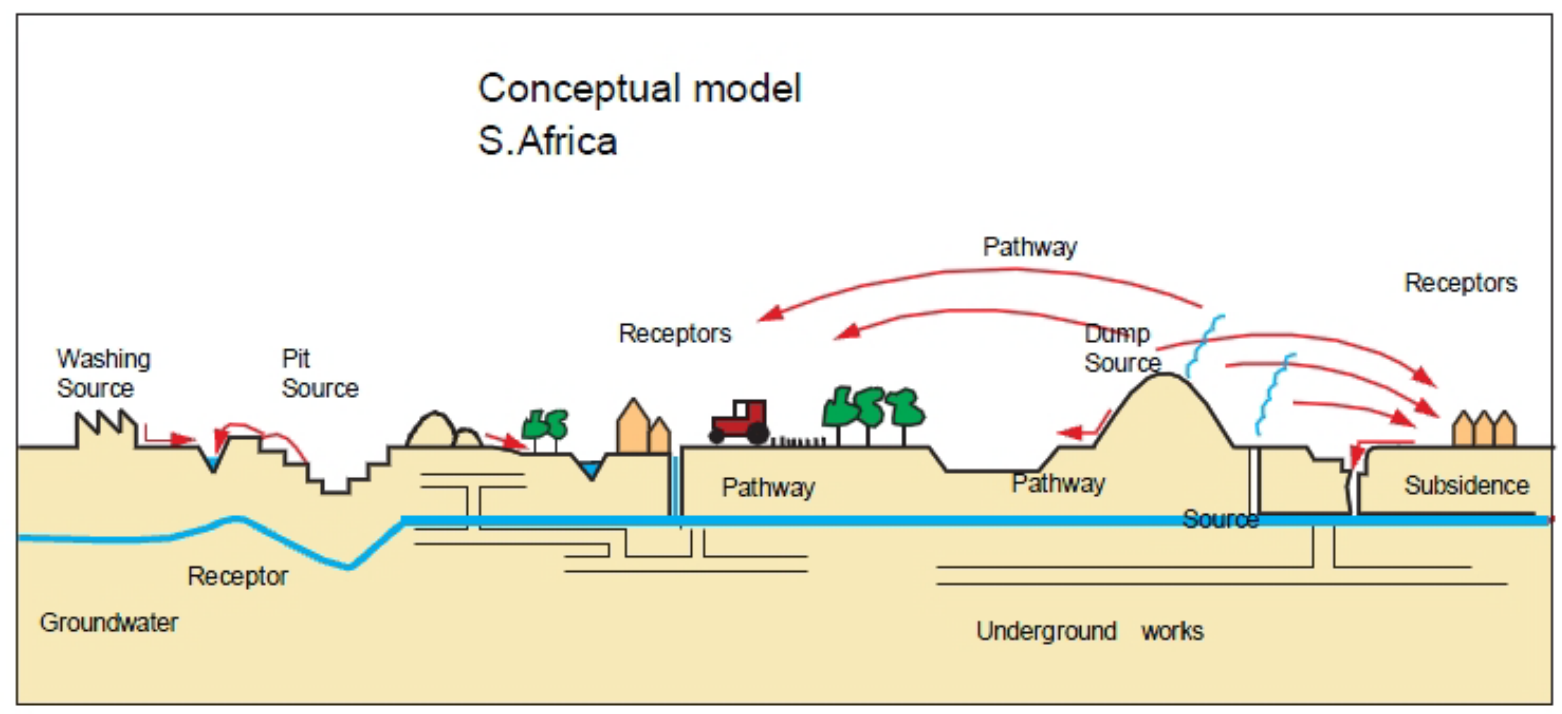

Figure 1 Conceptual site model for the South Africa test site at Witbank

Knowledge and expertise of the project partners, allied to local information, was also used to build conceptual site models of each site (e.g. Fig 1). These models were a vital step required to better understand the context and interplay between the environmental and societal indicators, and also served as an important stage in determining which EO techniques could be applied to monitor those indicators at each site.

Subsequently, a matrix was developed that integrated the indicators, the conceptual site models, and information on EO techniques in order to define which combination of EO datasets (i.e. satellite, airborne and in-situ) should be acquired at each site (Table 1). The EO data were acquired, processed and interpreted specifically to develop tools, methods and products in order to help ascertain and monitor the status of the site-specific indicators. It should also be noted that in this project, we consider EO to include appropriate in situ data collection and validation techniques, such as thermal and ASD measurements.

\section{TEST SITES AND INDICATORS}

The Sokolov lignite mining area is located in the Northwest of the Bohemia province in the Czech Republic. The area is affected by open cast mining activities and corresponding Acid Mine Drainage (AMD) processes. Airborne hyperspectral and TIR data cubes from surveys flown in 2009, 2010 and 2011 were the primary tool used for developing mineral mapping procedures, surface $\mathrm{pH}$ and water parameter mapping and vegetation health status models. In addition, change detection routines for tracking post-mining and rehabilitation activities were tested while elevation models were produced and used to model drainage patterns and corresponding potential pathways to receptors of any contaminants identified in the EO data.

The Witbank district in South Africa includes mines encompassing all stages of the lifecycle; from exploration and operating mines, to those undergoing closure or already abandoned. The major impact of mining in the area has been due to land degradation on the abandoned mine sites, partly caused by uncontrolled coal fires and associated water pollution. Regional and local scale time series analyses based on Worldview II, Landsat and TerraSAR-X imagery have been integrated with airborne FLIR and LiDAR surveys to map features including AMD, landuse change and subsurface coal fire high temperature events.

The third test site focuses on the tailings pond environment of the gold processing plant at Kazarman in Kyrgyzstan. The main concerns relate to the heavy metals content and the impact zone of a tailings dump. Current regular in situ monitoring of water resources and soil have been supplemented by very high resolution 
Table 1 Summary of EO data collected at the three test sites

\begin{tabular}{|c|c|c|c|c|c|c|}
\hline & RS Image data & & DEMs & & EO \& GIS & \\
\hline Site & Data set & Data type & Data set & Resolution & Data set & Data type \\
\hline Sokolov & $\begin{array}{l}\text { Hymap } 2009 \\
\text { Hymap } 2010 \\
\text { AHS } 2011 \\
\text { Orthopohoto } \\
\text { mosaic } \\
\text { CASI } \\
\text { ALI } \\
\text { ASTER }\end{array}$ & $\begin{array}{l}\text { Hyperspectral VNIR - } \\
\text { SWIR } \\
\text { Hyperspectral TIR } \\
\text { Aerial photographs } \\
\text { Hyperspectral VNIR } \\
10 \text { bands VNIR - } \\
\text { SWIR } \\
15 \text { bands VNIR - } \\
\text { SWIR - TIR }\end{array}$ & $\begin{array}{l}\text { Cartosat } 2009 \\
\text { Cartosat } 2010 \\
\text { Cartosat } 2011 \\
\text { GEODIS } \\
\text { ASTER }\end{array}$ & $\begin{array}{l}5 \mathrm{~m} \\
5 \mathrm{~m} \\
5 \mathrm{~m} \\
10 \mathrm{~m} \\
30 \mathrm{~m}\end{array}$ & $\begin{array}{l}\text { ASD spectra } \\
\text { TIR spectra } \\
\text { Temperature measurements } \\
\text { Dust measurements } \\
\text { Geology } \\
\text { Land cover } \\
\text { Topographic data }\end{array}$ & $\begin{array}{l}\text { Spectral library } \\
\text { Spectral library } \\
\text { Land cover } 2006\end{array}$ \\
\hline Witbank & $\begin{array}{l}\text { WorldView_II } \\
\text { Landsat TM } \\
\text { series } \\
\text { SPOT } \\
\text { FLIR survey } \\
\text { AISA dual } 2012\end{array}$ & $\begin{array}{l}8 \text { bands VNIR } \\
7 \text { bands VNIR - } \\
\text { SWIR } \\
2.5 \mathrm{~m} \text { color } \\
\text { Airborne TIR } \\
\\
\text { Hyperspectral VNIR - } \\
\text { SWIR }\end{array}$ & $\begin{array}{l}\text { WorldView_II } \\
\text { SRTM } \\
\text { LiDAR }\end{array}$ & $\begin{array}{l}5 \mathrm{~m} \\
90 \mathrm{~m} \\
2 \mathrm{~m}\end{array}$ & $\begin{array}{l}\text { ASD spectra } \\
\text { Temperature measurements } \\
\text { Dust measurements } \\
\text { GIS (tbd.) } \\
\text { ALERT }\end{array}$ & $\begin{array}{l}\text { Real time electrical } \\
\text { resistivity } \\
\text { tomography }\end{array}$ \\
\hline Makmal & $\begin{array}{l}\text { WorldView_II } \\
\text { Landsat TM } \\
\text { SPOT }\end{array}$ & $\begin{array}{l}8 \text { bands VNIR } \\
2.5 \mathrm{~m} \text { color }\end{array}$ & $\begin{array}{l}\text { WorldView_II } \\
\text { SRTM } \\
\text { ASTER }\end{array}$ & $\begin{array}{l}5 \mathrm{~m} \\
90 \mathrm{~m} \\
30 \mathrm{~m}\end{array}$ & $\begin{array}{l}\text { Geology } \\
\text { Chemical analyses } \\
\text { ASD spectra }\end{array}$ & \\
\hline
\end{tabular}

WorldView-II stereo data that have been used for DEM extraction, flow accumulation modelling tasks, and manual feature extraction / interpretation.

\section{EO PRODUCTS}

Appropriate EO products have been developed in response to land use, air quality, water quality, transport, geohazards and mass flow issues based on the environmental and societal indicators on different scales (local to regional). Due to the fact that the stakeholders have varying degrees of knowledge of mining techniques, EO or even computing (they range from local farmers or mining engineers to GIS experts in government departments) it was vital to present the products in a form of language that everyone would understand. They were also presented in a variety of formats i.e. paper (poster, booklet and leaflet) and digital (video, GeoPDF, GIS, visualisations and GoogleEarth) to ensure that they reached all of the intended audiences in a format that they found userfriendly, interactive and efficient.
Paper maps or posters are ideal as static representations of the situation, while GeoPDFs (e.g. Fig 2) in 2D and 3D formats are more interactive, with the functionality to zoom in to greater detail, to measure distances and areas, to turn layers on/off, and to view the terrain from any perspective. The stakeholders were also shown that the digital files can also be copied to devices such as iPADs and the GPS functionality used to investigate the results whist in the field.

To ensure the necessary reproducibility of the mapping and monitoring results, it was important to ensure that relevant geo-spatial information was produced with the needed accuracy, reflecting different demands, and that accepted standards and protocols (e.g. ISO TC 211) were considered. Potential improvements have furthermore to be combined with quality assessment techniques compliant with national and international guidelines under development, e.g. with EUFAR, QA4EO and GEOSS. This approach paves the way for the generation of standardized thematic application products. 


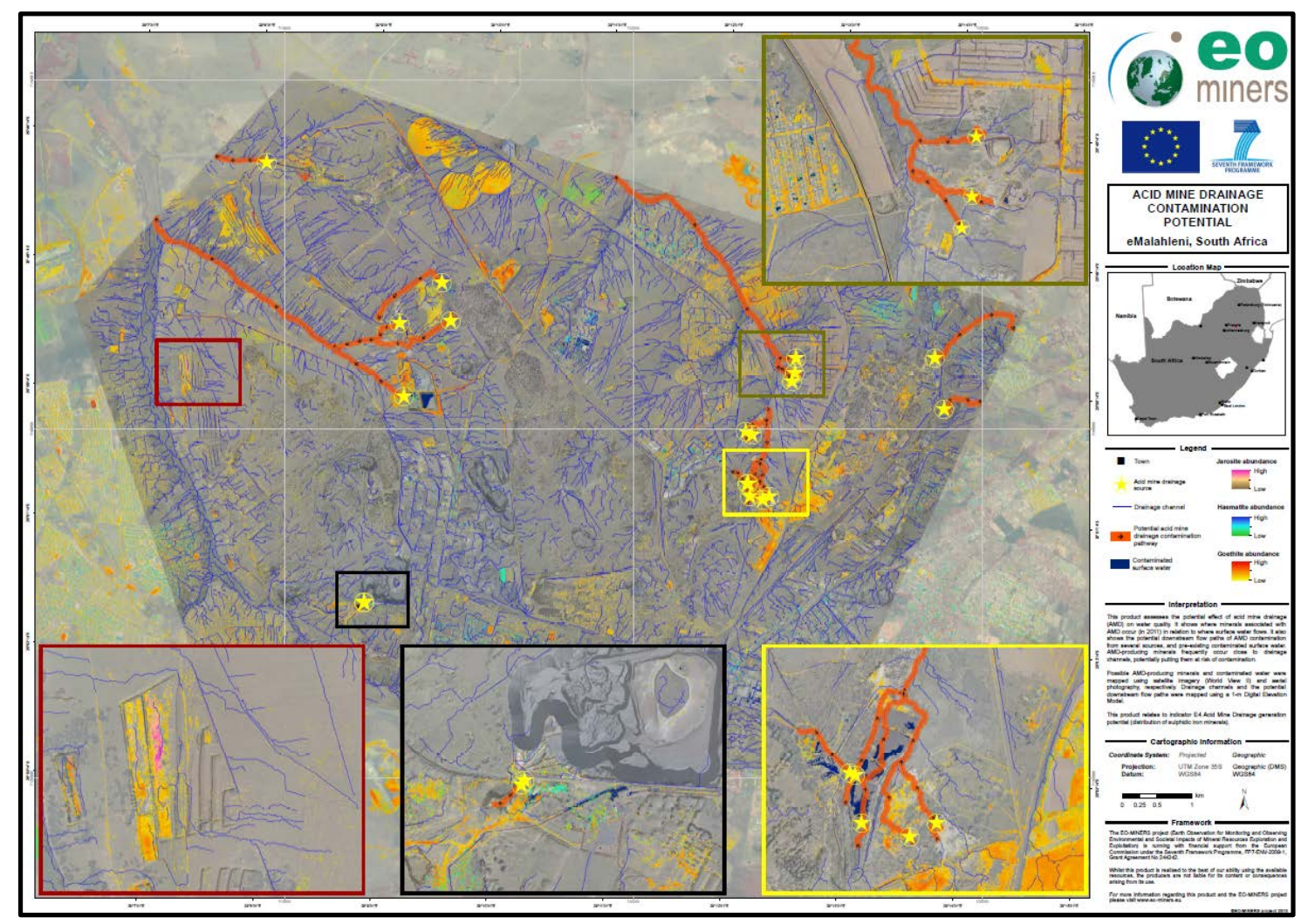

Figure 2 Example of a poster product (also available in GeoPDF format from www.eo-miners.eu)

Stakeholder workshops have already been held in the Czech Republic, South Africa and Kyrgyzstan. One of the main aims of the workshops was to introduce and demonstrate the novel EO products to the trialogue stakeholders, and to gain feedback on their comprehension and technical implementation. It was evident that the response from attendees (ranging from mining companies, government departments, NGOs and the local population) was positive and that EO can play a key role in providing more efficient and comprehensive assessments of miningrelated impacts on both the environment and society.

\section{CONCLUSIONS}

The aim of EO-MINERS is to bring into play EO-based methods and tools to facilitate and improve interaction between the mineral extractive industry and society in view of its sustainable development, while improving its societal acceptability. The EO data was collected in response to specific indicators at three sites, covering a range that occurs globally. The stakeholder dissemination meetings focussed on presenting the products and gaining feedback on their comprehension and technical implementation. The feedback has been positive, with the overriding view that the products are informative, and have helped to encourage constructive and objective discussions between the stakeholders in the trialogue.

\section{ACKNOWLEDGEMENTS}

The EO-MINERS project is financed by the European Commission under the $7^{\text {th }}$ Framework Programme, FP7-ENV-2009-1. This paper is published with the permission of the Executive Director of the British Geological Survey (BGSNERC). 